\title{
THE RECOGNITION AND REPRESENTATION OF POLAND IN MODERN KOREAN LITERATURE - FOCUSING ON 2 NOVELS WRITTEN IN LATE COLONIAL PERIOD
}

\author{
Kang Sok CHO \\ Inha University \\ Center for Korean Studies \\ 100 inharo, Nam-gu Incheon 22212, \\ South Korea \\ kscho@inha.ac.kr
}

\begin{abstract}
This paper examines the aspects of the recognition and representation of Eastern Europe in modern Korean literature, especially focusing on the case of Poland. The late colonial period(1930 1945) needs to be considered as significant phase when we are trying to grasp the major aspects of representation and recognition of Poland and Eastern Europe in modern Korean literature. In the literary works written by writers of late colonial period, such as Kim Kwang-gyun (김광균), Lee Hyo-sok (이효석), and Lee Tae-joon (이태준), we can observe that there were much similar historical and political situations between Poland and Korea. That's why Korean writers often tried to mention Poland's situation in metaphorical and analogical ways to express their political opinions, avoiding the censorship of Japanese government. This paper deals with those aspects in modern Korean literature.
\end{abstract}

Key words: Eastern Europe, colonial period, aesthetic universalism, Lee Hyo-sok, Lee Tae-joon 
근대한국문학 속에 묘사된 폴란드의 모습과 인식 - 일제식민지 시기 두 편의 단편소설을 중심으로

개략: 이 연구는 1930 년 대 후반과 1940 년 대에 씨어진 한국 소설 중에서 동유럽, 특히 폴란드와의 유비관계를 중요하게 다룬 소설의 정치적 무의식을 추적한다. 1930 년 대 후반과 1940 년대 초반의 소설에서 폴란드가 자주 언급되고 심지어 그것이 작품의 핵심 주제와 깊이 관계되는 것은 전혀 우연이 아니다. 일본 제국주의 세력이 본격적으로 태평양 전쟁 준비에 몰두함에 따라 피식민지 조선의 상황은 더욱 급박해졌다. 조선의 말과 글을 사용하는 것조차 공식적으로 금지되는 현실에서 정치적 상황에 대해 직접적으로 발언을 하기 어려운 작가들에게 폴란드는 우회적으로 참조할 수 있는 중요한 타자로서 기능했다.

키워드: 동유럽; 폴란드; 정치적 무의식; 심미적 보편주의; 타자

\title{
WIZERUNEK I SPOSÓB PRZEDSTAWIENIA POLSKI WE WSPÓŁCZESNEJ LITERATURZE KOREAŃSKIEJ - NA PRZYKLADZIE 2 POWIEŚCI Z OKRESU KOLONIALNEGO
}

\begin{abstract}
Abstrakt: Praca dotyczy wizerunku i sposobu przedstawiania Polski we wspólczesnej literaturze koreańskiej. Autor analizuje prace następujących koreańskich pisarzy: Kim Kwang-gyun (김광균), Lee Hyo-sok (이효석) oraz Lee Tae-joon (이태준) i wysuwa wniosek, że można zauważyć wiele podobieństw na płaszczyźnie politycznej i historycznej pomiędzy Polską i Koreą. $Z$ tego powodu koreańscy pisarze przedstawiają Polskę i sytuację w tym kraju w sposób metaforyczny. Wykorzystują przykład Polski do wyrażania własnych opinii politycznych i unikania cenzury japońskiego rządu.
\end{abstract}

Słowa klucze: Polska, okres kolonialny, uniwersalizm estetyczny, Lee Hyo-sok, Lee Tae-joon

\section{Preface}

In (South) Korea, the most well-known literary work, which is relevant with Poland, might be Kim Kwang-kyun's poem, <Chuilseojung 추일서정- The sentiment of an Autumn day>. Kim, Kwangkyun is talented at describing poetic objects with keen sense. The quotation helow is from the nnem orioinally published in the journal Inmunpyoungron(인문평론) in July, 1940. 
The fallen leaf is the bill of the Polish- refugee government It reminds me that

Autumn sky of Toruń, destroyed by artillery fire.

Even though Kim, Kwang-kyun has never been to Torun, the city is represented in this poem as an image of the grief of national ruin. Poland had undergone similar political situations to colonized Korea, so the image of Poland resonates with how Korean would feel under the socio-political context of the era. Poland had been frequently referred in Korean literary works during 193-1942. This phenomenon is neither provisional nor coincidental. Rather, it is the way how writers of colonized Korea reflect their own political situations through the representation of the other, Poland. The primary purpose of this paper is to examine those aspects Korean authors bring forth with the representation of Poland. I will focus on two novels, Yeosu (여수) and The century's daughter (세기의 딸) published in the period of the political turmoil right after the second Sino-Japanese War.

\section{Korean literature after 1937}

The second Sino-Japanese War broke out in 1937. Japanese colonial government tried to make Korea a massive military supply base. The Korean language was banned from schools in 1938 as part of a policy of cultural assimilation. And all Korean language publication were censored. Some of them were forcefully unified or closed down by Japanese colonial government. All the Korean-language publications were outlawed in 1941.

After the Sino-Japanese War, the policies and regulations of Japanese colonial government became more pronounced, so that Korean authors' work environment in terms of writing and publication became worse. It was very hard for authors to write literary works with their own value- system or worldview in the wake of this strict social milieu.

Hence, it is important to read the representations in the literary works carefully. It is not a coincidence that the representation of Po- 
land frequently appeared in Korean novel during that period. It is partly because Korean authors were not allowed to write what they wanted to say in quite a direct way. They could barely reveal their worldview with the representation of the other.

\section{Aesthetic Universalism}

Lee, Hyo-sok(1907-1942) is an archetypal novelist who is looking for aesthetic-universalism. His short story Yeosu(the traveler's melancholy) was published in 1939. The plot of Yeosu is simple. This story is about a road theatre company. The company named 'Serbian show' consists of Eastern Europeans such as Polish, Hungarian, and Czech. They left their home-countries, moved around a lot, and finally arrived at Korea. Mr. Kim, the painter who drew the advertising poster for the company feels affection for them. As the show has performed, sometimes they create tension with each others. But at the same time, they lean on each other for soothing homesickness and hard work. After the performance, they go separate ways. more. ${ }^{1}$

Let me quote some passages from this novel to understand

1) "Why is all Polish music so sad like that? Paderewski's music is gloomy, Chopin is the same"

2) "Yes, it is quite sad. I don't know the sadness of the country made its music so sad, or such a sorrowful music made the country sad"

3) "Starhov once dreamed of performing piano concert at the Warsaw national theatre. He wanted to be a world-class pianist. But his dream ended up with the disappearance of Poland."

Mr. Kim, the painter who drew the advertising poster for the 'Serbian Show,' has pity on Starhov, a polish performer, and sympa-

${ }^{1}$ Yeosu was serialized in Dong-A Ilbo (동아일보, The Dong-A Daily Newspaper) from 1939.11.29 to 1939.12.28. Passages are quoted from that newspaper. 
thizes with him. His sympathy for Starhov is originated from the same situation of national ruin of Korea. It is important to note that this novel was published in 1939. Around that time, Japan already won the Second Sino-Japanese War and was desperately preparing itself for the full-scale Pacific War. As the preparation for the Pacific War became more serious, the everyday life of people in the colonized Korea became wore off than before. And also, Korean language was strictly prohibited in all the level of school system. Lee, Hyo-sok could barely express the sorrow of national ruin with referring "the other", Poland.

1) "I have thought that the affection for Europe is not just an aimless longing for the exotic countries, but rather, it is the expression of thirsty for freedom."

2) "Europe might also be biased, stingy, and disappointing. But utopia won't happen, so some sort of prejudice can't be avoidable in the world. Longing for Europe won't probably be resolved unless I step on the land. This longing is natural and understandable."

3) "Even though some parts of the world keep resisting European influence, the modern world has been colored by European culture. In this sense, nostalgia for Europe, the cradle of modern civilization, might be similar with the longing for my own hometown. My mind will be the same with Starhov's yearning for Europe. Our longing for Europe is sort of longing for the hometown.

Lee, Hyo-sok's Europe-intentionality is originated from the nostalgia for the hometown. This nostalgia is neither orientalism, nor occidentalism.

Japan justified the Pacific War with so-called "The Greater East Asia Co-prosperity Sphere (Dai-tō-a Kyōeiken 大東亞共榮圈).” Some Japanese thinkers insisted that the western-style modernity has been declined. So, the East should take the leading role to establish the new civilization instead of the West.

However, Lee Hyo-sok's primary concern is neither the East, nor the West. His nostalgia is about somewhere far away from 'here and now.' It might be considered as an ultimate nostalgia in that this nostalgia has intentionality for the origin of human being.

In this sense, Lee's nostalgia is sort of romantic yearning. Even though this yearning is somehow abstract and even seems to be uncritical, this can be considered as an indirect critique on the life of 
'here and now.' In that sense we can call this attitude as aesthetic universalism meaning pursuing for the universal reconciliation. ${ }^{2}$ Lee's aesthetic universalism, which contains utopian impulse, yields the critique on the life in this earthly world.

\section{'The Century of the Fact', Science, and Patriotism}

Lee, Moo-young(1908-1960) is the novelist who deals with the reality of rural areas based on agricultural economy. His novel The Century's daughter(세기의 딸) is about the life-story of Marie Curie, a Polish and naturalized-French physicist and chemist. This novel was serialized in Dong-A Ilbo(The Dong-A daily newspaper) from Oct 10, 1939. Unfortunately, this novel was ended incomplete because DongA Ilbo was compulsorily closed off by the Japanese colonial government in October, 1940. This novel is a fiction based on the biography of Marie Curie, which is written by Marie Curie's daughter, Éve Curie.

Lee, Moo-young mentions his intention of this novel:

"I didn't take Marie Curie as a subject matter due to her popularity or the request of the newspaper that I am supposed to publish the novel. Rather, she is from a weak nation, Poland. More crucially, her life is the record of resistance against the world power which invaded her mother-country. I intended to make 15 million Korean woman more patriotic."

“The Century's daughter foregrounds Marie Curie's patriotism and her mental anguish than her achievement as a scientist. I have thought that the affection for Europe is not just an aimless longing for the exotic countries, but rather, it is the expression of thirsty for freedom."

\footnotetext{
${ }^{2}$ Terry Eagleton, $\ulcorner$ Nationalism: Irony and Commitment $\lrcorner$, Nationalism, Colonialism, and Literature, Univ Of Minnesota Press; 1 edition (September 17, 1990)
} 
Lee, Moo-young wrote this novel in 1939. His intension of writing this novel needs to be posited in the socio-political context of 1939. Let's take a look at some parts of prologue. ${ }^{3}$

1) "Laugh heartily, people of Poland"

2) "Warsaw, the capital city of Poland was subjugated by and assimilated with the Russian Empire. Meanwhile, the old town of Warsaw seemed as though it was ruined castle. Its avenues seemed to be lonely. However, this old town was the last area that the soul of Poland and its tradition was preserved."

3) "Violence can never be beauty. The beauty of violence is cruelty. Its expression is destruction. The beauty of the weak was mercilessly destroyed by the grand power of St. Petersburg. The daily life, language, and ideas of the people of Poland were trampled down by the power."

The quotations above describe the political atmosphere of Poland in the late 19th century. And at the same time, the descriptions reflect Lee, Moo-young's perspective on the socio-political context of Korea in 1939. The descriptions of Poland under the rule of the Russian Empire and the explanations for the prohibition of motherlanguage are not just for depicting the situation of Poland. The author's intention of the descriptions can be easily presumed. "Poland, Oh! the beautiful virgin named Poland"; this quote explicitly uncovers what the intent of this novel is.

Following quotation is posited in the same context with the quotation above:

"Current Russian politicians are digging their own grave competitively. The just has never been defeated since the human society appears. The just is always in the human being in general, not in the small group of people. However, they ignore, persecute, and even kill the people. We have to denounce any despotic form of government as we regain liberty. Politics should be rendered by liberty and the people [....] The liberty always resists against any despotic regime."

${ }^{3}$ The Century's daughter was serialized in Dong-A Ilbo(동아일보, The Dong-A Daily Newspaper) from 1939.10.10 to 1940.08.11. Passaged are quoted from that newspaper. 
As we have seen, Marie Curies' Poland overlaps with the reality of Korea in this novel. Now, we need to take a look at the second topic of this novel, the attitude for 'science.'

"The Century of the Fact" was one of the philosophical mottos that Japanese imperialism verifies the Pacific War and the logic of "the Great East Asia Co-prosperity Sphere." This phrase is originated from Paul Valéry. He says that "the century of order" which has been sustained by the European ethos for a long time had declined by the modern empirical science. Actually, 'the universal order' had given somehow abstract accounts for the pre-modern world. As the order had collapsed down, the lacuna was taken by 'the fact.' In other words, 'The century of the fact' arrived. Paul Valéry's remarks that 'the century of order' has gone, and 'the century of the fact' has come instead. It means that the era of the Eurocentric universalism declined.

Meanwhile, Japanese thinkers in the late 1930s appropriated this phrase for their own sake. They insisted that the Western modernity had declined and 'the Great East Asia' emerged as the center of the world history. According to them, this great change should be accepted not only as the significant event in the history of civilization, but also as the fact that we ought to accept without a doubt. This is the way in which Japanese thinkers in the late 1930s appropriated the remark of Paul Valéry.

This logic of 'acceptance of the fact' led Japan to the logic of overcoming western modernity, and to the logic of the Great East Asia Co-prosperity Sphere and the establishment of new civilization. In this way, 'the Century of the Fact' was transformed into the logic of 'what should do.'

Lee, Moo-young took Marie Curie as the protagonist of his novel considering that Poland and Korea were confronting the similar situation. And also, taking Marie Curie, an outstanding scientist, as the protagonist was somehow strategic choice for criticizing the logic of 'the Century of the Fact,' which was appropriated and transformed by Japanese thinkers to verify the logic of 'the Great East Asia Coprosperity Sphere.' Let's take a look at Marie Curie's lines in the novel.

"Scientist does not need to abandon his/her country. The science is a discipline for human being in general. That's true. However, if each nation and 
each individual cannot be happy, happiness of human being will also be impossible."

At this point, Lee, Moo-young emphasizes that the science is not just confined as a tool of totalitarianism. The author delivers his own idea of science, which is a critique on the Great East Asia Coprosperity Sphere, with the voice of Marie Curie, the protagonist. This novel partly aims at criticizing the false logic of Japanese imperialism, so it weighs not on the Marie Curie's achievement as a scientist, but on her longing for emancipation of Poland. Consequently, this novel shows us that the Japan's totalitarian appropriation of the logic of 'the Century of the Fact' cannot be accepted.

\section{Conclusion}

It is not just coincidental that Poland was frequently referred in Korean novels and the representation of Poland is deeply engaged in the main subject of novel in the late 1930s and the early 1940s. In that period, Japan's preparation of the Pacific War became more serious. The colonized Korea became a massive supply base for the war. Additionally, Korean language was officially prohibited in all the level of school system. Korean authors could not speak of social reality in direct way. As I have discussed, Poland allowed Korean writers to reflect themselves, and more crucially, it became a significant reference with regard to develop the counter-logic against Japanese imperialism.

\section{References}

Cha, Seung-gi \& Jung, Jong-hyun 편, 2006. 『서인식전집 1, 2』. 서울: 역락. 
Cha, Seung-gi. 2010. 「'사실의 세기'. 우연성, 협력의 윤리」, 『전쟁 하는 신민, 식민지의 국민문화』. 서울:소명출판.

Cho, Kang-sok. 2012. 「도착적 보편과 마주선 특수자의 요청」 『한 국학연구』, 27 집. 인천: 인하대학교 한국학연구소.

Dakeuchi Yoshimi(竹內好) 지음, Seo, Kwang-duk \& Baek, Ji-woon 옮김. 2004.「근대의 초극」, 『일본과 아시아』. 서울: 소명 출판.

Hiromatz Wataru(廣松涉) 지음, Kim, Hang 옮김. 『근대초극론』, 서 울:민음사.

Jun, Woo-hyung, 2013. 「이효석 소설의 할리우드 표상과 유럽 영 화라는 상상의 공동체」,

Jung, Jong-hyun. 2008, 「사실, 과학 그리고 문학의 신생」. 상허학 보 23 집. 『대중서사연구』.

Lee, Hyo-sok. 「여수」. 동아일보, 1939.11.29-1939.12.28

Lee, Hyo-sok. 2007. 『메밀꽃 필 무렵』. 서울:문학과지성사.

Lee, Moo-young, 「세기의 딸」. 동아일보. 1939.10.10-1940.06.27

Lee, Moo-young, 1975, 「세기의 딸」, 『이무영대표작전집 3 』. 서울: 신구문화사.

Terry Eagleton, $\ulcorner$ Nationalism: Irony and Commitment $\lrcorner$, Nationalism, Colonial-ism, and Literature, University of Minnesota Press; 1 edition (September 17, 1990). 